\title{
Effect of Foliar Application of Different Sources of Nutrients on Growth and Yield of Blackgram under Irrigated Conditions
}

\author{
B. Devaraju* and T. Senthivel
}

School of Agriculture and Animal Sciences, Gandhigram Rural Institute, (Deemed to be university), Gandhigram, Dindigul Dist., Tamil Nadu, India

*Corresponding author

\section{A B S T R A C T}

\section{Keywords}

Pulse wonder, All19, DAP

Article Info

Accepted:

26 December 2017

Available Online:

10 January 2018
Field investigation was carried out during the kharif seasons of 2016 and 2017 at farmer field of Melakkottai, Attur block of Dindigul district, Tamilnadu to investigate the effect of foliar application of different source of nutrients resulted in significant increase in growth and yield characters of blackgram. The foliar application of pulse wonder @ $5 \mathrm{~kg} / \mathrm{ha}$ at flowering and 15 days after $1^{\text {st }}$ spray was significantly increased number of pods / plant, number of seeds / pod, biomass and grain yield of blackgram.

\section{Introduction}

Blackgram (Vigna mungo L.) is one of the most important pulse crops of irrigated areas grown though out the country. Blackgram seed contains 25-26 per cent proteins, 60 per cent carbohydrates, 1.5 per cent fat, and minerals combination, Amino acid and essential vitamins etc. It is used as nutritive fodder especially for milch cattle. It is also used as a green manuring crop. Blackgram is native of India and originated from Phaseolus sublobatus a wild plant.

In India total pulses production was estimated 64.4 million tonnes from 72.3 million hectare area with productivity of $890 \mathrm{~kg} / \mathrm{ha}$ in the triennium ending 2010-11.
The potential of blackgram is very low because of the fact that the crop is mainly grown in rain-fed condition with poor management practices and also due to various physiological, biochemical as well as inherent factors associated with the crops. Apart from the genetic makeup, the physiological factors viz., insufficient portioning assimilates, poor pod setting due to the flower abscission and lack of nutrients during critical stage at crop growth, coupled with a number of pests and disease (Mahala et al., 2001) constitute the major constraints for the poor yield.

The productivity of blackgram in our country is very low, because, there is need for enhancement of the productivity of blackgram by proper Agronomic practices. One among 
them is foliar application of nutrient sources for exploiting genetic potential of the crop. This is considered to be an efficient and economic method of supplementing part of nutrients requirement of critical stages. Foliar application is credited with the advantage of quick and efficient utilization of nutrients elimination of losses through leaching, fixation and regulating the uptake of nutrients by plant (Manonmani and Srimathi, 2009). Since foliar nutrients usually penetrate the leaf cuticle or stomata and enters the cells facilitating easy and rapid utilization of nutrients. Foliar application of $\mathrm{N}$ at particular stage may solve the slow growth, nodule senescence and low seed yield of pulse without involving root absorption at critical stage (Latha and Nadanasabady 2003).

Foliar application of nutrient and growth regulator at pre-flowering and flowering stage was seen on reduction in flower drop percentage in blackgram (Ganapathy et al., 2008)

\section{Materials and Methods}

A field experiment was conducted at the farmer field of Melakkottai village of Attur block, Dindigul district, Tamil Nadu on clay loam having 7.9 PH. The available NPK 256, $14.2,340 \mathrm{~kg} / \mathrm{ha}$, respectively.

The experiment consisted of nine treatments, and was laid out in a randomized block design with three replications. The treatments are as follows:

$\mathrm{T}_{1}=\mathrm{DAP} @ 2 \%$ at flowering and 15 days after $1^{\text {st }}$ spray.

$\mathrm{T}_{2}=$ Pulse wonder @ $2.5 \mathrm{~kg} / \mathrm{ha}$ at flowering and 15 days after $1^{\text {st }}$ spray.

$\mathrm{T}_{3}=$ Pulse wonder $@ 5 \mathrm{~kg} / \mathrm{ha}$ at flowering and 15 days after $1^{\text {st }}$ spray.
$\mathrm{T}_{4}=$ Pulse wonder @ $7.5 \mathrm{~kg} / \mathrm{ha}$ at flowering and 15 days after $1^{\text {st }}$ spray

$\mathrm{T}_{5}=$ All $19 @ 0.5 \%$ at flowering and 15 days after $1^{\text {st }}$ spray

$\mathrm{T}_{6}=$ All $19 @ 1.0 \%$ at flowering and 15 days after $1^{\text {st }}$ spray

$\mathrm{T}_{7}=$ All $19 @ 1.5 \%$ at flowering and 15 days after $1^{\text {st }}$ spray

$\mathrm{T}_{8}=$ All $19 @ 2.0 \%$ at flowering and 15 days after $1^{\text {st }}$ spray

$\mathrm{T}_{9}=$ Control

An uniform dose of 50:20:20:20 kg NPKS/ha were applied as basal through DAP, MOP and Gypsum respectively in all the experimental plots. The required quantity of foliar nutrients and water for each plot were calculated to prepare solution and sprayed uniformly by hand sprayer using conical shaped nozzle. The blackgram crop was harvested, when the pods were fully ripened and turned black. Threshed seeds were sun-dried for 2-3 days to reduce the moisture content and then the seed yield per plot was recorded.

Gross returns were calculated by taking the sale price of blackgram at Rs 65 per $\mathrm{kg}$. Net returns (Rs/ha) were calculated as Net returns $=$ Gross returns - cost of cultivation including the cost of individual treatments. Benefits cost ratio was calculated after dividing net returns with the cost of cultivation.

\section{Results and Discussion}

\section{Crop growth characters}

Plant height: Plant height is the important character of the vegetative phase to influence the yield of crop. The data pointed that application of pulse wonder @ $5 \mathrm{~kg} / \mathrm{ha}$ 
flowering and 15 days after $1^{\text {st }}$ spray (T3) recorded maximum plant height, which was significantly superior than rest of treatments, expect application of All 19 @ 1\% flowering and 15 days after $1^{\text {st }}$ spray (T6). The minimum height of the plant height was recorded in control treatment. The significant increase of plant height was due to the internode elongation and the vigorous root growth of the crop. Manivannan et al., (2003) concluded that Rhizobium seed treatment and foliar application of microsol (NPK and chelated micronutrients) recorded markably higher leaf area index, dry matter production and crop growth rate. The application of DAP, TNAU pulse wonder, humicacid based micronutrients mixture as foliar spray significantly improved the yield attributing characters by reducing flower shedding and resulted in increasing number of pods/plant (Ravishankar et al., 2013 and Babu, 2017).

\section{Dry matter production}

At 50 DAS, the application of pulse wonder @ $5 \mathrm{~kg} / \mathrm{ha}$ at flowering and 15 days after $1^{\text {st }}$ spray (T3) was recorded maximum dry matter production per plant, which was significantly better than remaining treatments and as per with treatment at All 19 @ 1\% flowering 15 days after $1^{\text {st }}$ spray. The significant increase of dry weight/plant was due to the fact that nitrogen helps in maintaining higher auxin level which might have resulted in better plant height, leaf area and more chlorophyll content of the leaves. The growth components viz., plant height, number of branches and dry matter production were enhanced due to increased dose of RDF along with foliar spray of nutrients (Murugesa bhopathi, 2012)

\section{Yield attributes}

The blackgram yield attributes viz., number of pods / plant, no. of seed / pod. and 100 gram wt.
However, foliar application pulses wonder @ $5 \mathrm{~kg} / \mathrm{ha}$ flowering and 15 days after $1^{\text {st }}$ DAS spray of crop growth resulted in significantly higher number of pods / plant than other foliar spray treatments. Higher supply of all nutrients at flower initiation and pod formation stages of crop growth might have caused efficient translocation of photosynthates from source to sink. Further, the foliar applied nitrogen and phosphorus at the initial stages might have been effectively absorbed and trans-located to the pods resulting in more number of pods plant ${ }^{-1}$. The results obtained by Subba Rami Reddy et al., (2011).

The data disclosed that the efficient and foliar nutrients on number of seeds /pod was observed as non-significant.

The maximum number of seed per pod was recorded in both the treatments applications of pulse wonder @ $5 \mathrm{~kg} / \mathrm{ha}$ and application of All $19 @ 1 \%$ spray of flowering and 15 day after $1^{\text {st }}$ spray.

The application of pulse wonder @ $5 \mathrm{~kg} / \mathrm{ha}$ and flowering 15 days after spray gave significantly higher grain yield than other treatments. It was statistically at par with treatments application of All 19 @ $1 \%$ flowering and 15 days after spray.

The increase in yield might be due to enhanced yield attributes like number of pods plant $^{-1}$, number of seed $\operatorname{pod}^{-1}$. It is due to increased uptake of nutrients by blackgram by effective translocation of nutrients from sink to reproductive area of crop. The positive effect of $\mathrm{P}$ in increasing the grain yield of soybeans was noticed by Abbas et al., (1994) and Mathan et al., (1996) in blackgram.

From the experimental study it is concluded that different treatments has positive effect on yield, and growth of blackgram (Table 1 and 2). 
Table.1 Effect of foliar application of different sources of nutrients practices on growth attributes of blackgram

\begin{tabular}{|c|c|c|c|c|c|}
\hline Treatments & $\begin{array}{l}\text { Plant ht } \\
(\mathrm{cm})\end{array}$ & $\begin{array}{l}\text { branches/ } \\
\text { plant (no.) }\end{array}$ & $\begin{array}{c}\text { Dry wt }(\mathrm{g}) / \\
\text { Plant at } \\
\text { 50 DAS }\end{array}$ & $\begin{array}{l}\text { Crop growth } \\
\text { rate } \\
\text { (g/m2/day) at } \\
\text { 45-60 DAS }\end{array}$ & $\begin{array}{c}\text { Relative } \\
\text { Growth rate } \\
\text { (g/g/day) at 45- } \\
\text { 60 DAS }\end{array}$ \\
\hline $\begin{array}{l}\text { T1- DAP @ } 2 \% \text { at flowering and } 15 \text { days } \\
\text { after } 1^{\text {st }} \text { spray }\end{array}$ & 50.10 & 5.58 & 9.78 & 17.87 & 0.041 \\
\hline $\begin{array}{l}\text { T2 - Pulse wonder @ } 2.5 \mathrm{~kg} / \mathrm{ha} \text { at flowering } \\
\text { and } 15 \text { days after } 1^{\text {st }} \text { spray. }\end{array}$ & 50.55 & 5.52 & 10.11 & 23.12 & 0.048 \\
\hline $\begin{array}{l}\text { T3- Pulse wonder @ } 5 \mathrm{~kg} / \mathrm{ha} \text { at flowering } \\
\text { and } 15 \text { days after } 1^{\text {st }} \text { spray. }\end{array}$ & 52.50 & 6.12 & 12.60 & 31.75 & 0.056 \\
\hline $\begin{array}{l}\text { T4- Pulse wonder @ } 7.5 \mathrm{~kg} / \mathrm{ha} \text { at flowering } \\
\text { and } 15 \text { days after } 1^{\text {st }} \text { spray }\end{array}$ & 51.45 & 5.97 & 12.12 & 29.87 & 0.054 \\
\hline $\begin{array}{l}\text { T5 - All } 19 @ 0.5 \% \text { at flowering and } 15 \\
\text { days after } 1^{\text {st }} \text { spray }\end{array}$ & 50.25 & 5.37 & 10.35 & 23.75 & 0.048 \\
\hline $\begin{array}{l}\text { T6 - All } 19 @ 1.0 \% \text { at flowering and } 15 \\
\text { days after } 1^{\text {st }} \text { spray }\end{array}$ & 52.20 & 5.82 & 12.18 & 31.88 & 0.059 \\
\hline $\begin{array}{l}\text { T7- All } 19 @ 1.5 \% \text { at flowering and } 15 \\
\text { days after } 1^{\text {st }} \text { spray }\end{array}$ & 50.55 & 5.79 & 11.70 & 28.38 & 0.052 \\
\hline $\begin{array}{l}\text { T8-All } 19 @ 2.0 \% \text { at flowering and } 15 \\
\text { days after } 1^{\text {st }} \text { spray }\end{array}$ & 46.95 & 5.25 & 10.05 & 46.95 & 0.047 \\
\hline T9 - Control & 42.00 & 4.98 & 8.40 & 17.23 & 0.035 \\
\hline SEd & 0.64 & 0.07 & 0.48 & 2.21 & 0.003 \\
\hline C.D $5 \%$ & 1.92 & 0.23 & 1.44 & 6.62 & 0.009 \\
\hline
\end{tabular}

Table.2 Effect of foliar application of different sources of nutrients practices on yield attributes of blackgram

\begin{tabular}{|c|c|c|c|c|c|c|c|}
\hline Treatments & $\begin{array}{l}\text { Pods/Plant } \\
\text { (No.) }\end{array}$ & $\begin{array}{l}\text { Seeds/Pod } \\
\text { (No.) }\end{array}$ & $\begin{array}{l}\text { Grain } \\
\text { Yield } \\
(\mathrm{kg} / \mathrm{ha}\end{array}$ & $\begin{array}{l}\text { Straw } \\
\text { Yield } \\
(\mathrm{kg} / \mathrm{lr})\end{array}$ & $\begin{array}{l}\text { Harvest } \\
\text { Index } \\
(\%)\end{array}$ & $\begin{array}{l}\text { Net } \\
\text { Return } \\
(\text { Rs) }\end{array}$ & $\begin{array}{l}\text { Benefit } \\
\text { Cost } \\
\text { Ratio }\end{array}$ \\
\hline $\begin{array}{l}\text { T1-DAP @ } 2 \% \text { at flowering and } \\
15 \text { days after } 1^{\text {st }} \text { spray }\end{array}$ & 17.01 & 5.92 & 562.40 & 1010.80 & 33.95 & 9015.50 & 1.46 \\
\hline $\begin{array}{l}\text { T2 - Pulse wonder @ } 2.5 \mathrm{~kg} / \mathrm{ha} \text { at } \\
\text { flowering and } 15 \text { days after } 1^{\text {st }} \\
\text { spray. }\end{array}$ & 16.76 & 5.58 & 553.85 & 993.70 & 35.62 & 8493.00 & 1.43 \\
\hline $\begin{array}{l}\text { T3- Pulse wonder @ } 5 \mathrm{~kg} / \mathrm{ha} \text { at } \\
\text { flowering and } 15 \text { days after } 1^{\text {st }} \\
\text { spray. }\end{array}$ & 17.58 & 6.18 & 870.20 & 1450.65 & 33.93 & 22149.25 & 2.19 \\
\hline $\begin{array}{l}\text { T4- Pulse wonder @ } 7.5 \mathrm{~kg} / \mathrm{ha} \text { at } \\
\text { flowering and } 15 \text { days after } 1^{\text {st }} \\
\text { spray }\end{array}$ & 16.94 & 6.18 & 589.00 & 1002.25 & 35.15 & 9642.50 & 1.49 \\
\hline $\begin{array}{l}\text { T5 - All } 19 @ 0.5 \% \text { at flowering } \\
\text { and } 15 \text { days after } 1^{\text {st }} \text { spray }\end{array}$ & 16.94 & 5.54 & 518.70 & 931.95 & 33.96 & 6897.00 & 1.34 \\
\hline $\begin{array}{l}\text { T6 - All } 19 @ 1.0 \% \text { at flowering } \\
\text { and } 15 \text { days after } 1^{\text {st }} \text { spray }\end{array}$ & 17.01 & 6.18 & 826.50 & 1398.40 & 35.28 & 19095.95 & 1.95 \\
\hline $\begin{array}{l}\text { T7- All } 19 @ 1.5 \% \text { at flowering } \\
\text { and } 15 \text { days after } 1^{\text {st }} \text { spray }\end{array}$ & 16.63 & 5.96 & 562.40 & 940.50 & 35.53 & 8341.00 & 1.42 \\
\hline $\begin{array}{l}\text { T8- All } 19 @ 2.0 \% \text { at flowering } \\
\text { and } 15 \text { days after } 1^{\text {st }} \text { spray }\end{array}$ & 16.94 & 5.67 & 510.15 & 949.05 & 33.21 & 5670.55 & 1.25 \\
\hline T9 - Control & 10.61 & 5.32 & 421.80 & 739.10 & 34.54 & 2643.85 & 1.10 \\
\hline SEd & 0.22 & 0.21 & 24.70 & 52.25 & 0.21 & & \\
\hline C.D $5 \%$ & 0.67 & $\mathrm{~N}, \mathrm{~S}$ & 78.85 & 157.70 & $\mathrm{~N}, \mathrm{~S}$ & & \\
\hline
\end{tabular}


Applications of pulse wonder @ $5 \mathrm{~kg} / \mathrm{ha}$ spray at flowering and 15 days after spray gave the maximum yield and higher net return. Hence, the treatment of application of All 19 @1\% spray at flowering and 15 days after spray yield net returns which was at par with treatments of pulse wonder @ $5 \mathrm{~kg} / \mathrm{ha}$ at flowering 15 days after spray. So, this experiment concluded that application of pulse wonder @ $5 \mathrm{~kg} / \mathrm{ha}$ at flowering, 15 days after spray is more economic than application of All19@1\% spray at flowering and 15 days after $1^{\text {st }}$ spray.

\section{Abbreviations used}

DAP - Di Ammonium Phosphate

DAS - Days after sowing

MOP - Murate of Potash

$\mathrm{Ha}$ - Hectare

NPK - Nitrogen, Prosperous and Potash

NPKS - Nitrogen, Prosperous, Potash and

Sulphur

RDF - Recommended dose of fertilizer

\section{References}

Abbas, M. Singh, M.P, Nigam, K.P and Kandalkar, V.S. 1994. Effect of Phosphorus, Plant density and plant type on yield attributing characters of soybean (Glycine max). Indian J.Agron., 39:249255.

Babu, S. 2017. Enhancement of Blackgram productivity through soil and foliar application of nutrients. Proceedings of $71^{\text {st }}$ The IRES international conference, Kualahumpur, Malaysia, Ist-2nd June 2017. Ganapathy, M.G. Baradhan and N. Ramesh. 2008.
Effect of Foliar nutrition on re-productive efficiency and grain yield of rice fallow pulses. Legume Res., 31; 142-144.

Latha, M.R and Nadanasababady, T. 2003. Foliar nutrition in crops. Agric.Rev., 24(3):229234

Mahala, C.P.S., Dadheech, R.C. and Kulhari, R.K. 2001. Effect of plant growth regulators and yield of Black gram at varying levels of phosphorus. Crop Res. 18(1): 163-165

Manivannan, V., Thanunathan, K., Imayavaramban, $\mathrm{V}$. and Ramanathan, N. 2003. Growth and growth analysis of ricefallow blackgram as influenced by foliar application of nutrients with and without Rhizobium seed inoculation. Legume Research, 26(4): 296-299.

Manonmani, V. and Srimathi, P. 2009. Influence of mother crop nutrition on seed and quality of balckgram. Madras Agric. J., 96(16): 125-128.

Mathan, K. K., Francis, H. J. and Ramanathan, S. P. 1996. Response of blackgram (Phaseolus mungo) to fertilization and rhizobium inoculation. Indian Journal of Agronomy; 41(1): 74-77.

Murugesa Bhoopathi, P. 2012. TNAU develops a pulse wonder to increase production era. The times of India, Jan. 15.

Ravisankar, N, B. Chandrasekaran, K. Sathiyamoorthy and T.N. Balasubramanian, 2003. Effect of agronomic practices for multi blooming in greengram. Madras Agric. J., Vol.90, No: 1-3, pp. 166-169

Subba Rami Reddy, A, J. Sateesh Babu., M. Chandra Sekhar Reddy, M. Mujeeb Khan and M. Murali Rao. 2011. Integrated nutrient management in pigeon pea (Cajanus cajan) Int. J, Appl. Boil and Pharmaceutical Tech., Vol 2, pp. 467-470

\section{How to cite this article:}

Devaraju, B. and Senthivel, T. 2018. Effect of Foliar Application of Different Sources of Nutrients on Growth and Yield of Blackgram under Irrigated Conditions. Int.J.Curr.Microbiol.App.Sci. 7(01): 3105-3109. doi: https://doi.org/10.20546/ijcmas.2018.701.368 